МАЙОРОВ В.В.

\title{
ДО ПИТАННЯ ЕФЕКТИВНОСТІ РЕФОРМ В ОРГАНАХ ТА ПІДРОЗДІЛАХ НАЦІОНАЛЬНОЇ ПОЛІЦІЇ
}

Стаття присвячена питанням висвітленню окремих актуальних проблемних питань діяльності органів та підрозділів поліції, дослідженню їх сутності та пропонуванню шляхів вирішення.

Ц статті зазначається, що нині ефективність діяльності Національної поліції щодо захисту прав і свобод людини та громадянина, протидії злочинності та забезпечення правопорядку в державі полягає в розробці нових підходів і моделей формування іiі діяльності, вирішенні тих проблем, які ускладнюють або роблять неефективну діяльність поліції з виконання поставлених перед нею завдань. Тому висвітлення проблемних аспектів у діяльності поліції, які потребують вирішення, формування шляхів удосконалення діяльності у визначених сферах $\epsilon$ актуальним питанням.

У статті звертається увага на те, що Національну поліцію як окремий орган виконавчої влади характеризує: служіння суспільству шляхом забезпечення охорони прав і свобод людини, протидії злочинності, підтримання публічної безпеки і порядку; вона виступає від імені держави; ії діяльність спрямовується та координується Кабінетом Міністрів України через Міністра внутрішніх справ України. 3 моменту створення Національної поліції України як окремого центрального органу виконавчої влади вона перебуває в системному процесі розбудови. Тому постійні зміни в суспільному житті, реформи, що тривають у системі поліції, потребують постійного вивчення питань організаційно-правового, нормативного, інформаційного забезпечення поліції з метою подальшого пошуку шляхів покращення відповідних напрямів діяльності поліції.

У статті робиться висновок, що вдосконалення механізмів інформаційно-аналітичного забезпечення Національної поліції потребує створення концепції розвитку інформаційно-аналітичного забезпечення поліції на основі сучасних інформаційних технологій. Система Національної поліції досі не позбавилась певних нормативних та організаційних прогалин у власній діяльності, які потребують відповідного наукового опрацювання та вирішення, зокрема в частині вдосконалення нормативно-правового регулювання функціонування системи Національної поліції. Оцінка ефективності діяльності поліції немає обмежуватися таким показником, як рівень довіри населення до поліції.

Ключові слова: реформи, полічія, Національна полічія, МВС Украӥни, концепція, удосконалення.

The article is devoted to the issues of highlighting some topical issues of concern for the activities of police bodies and units, investigating their nature and proposing ways of solving them.

The article states that today the effectiveness of the activities of the National Police in protecting the rights and freedoms of the individual and the citizen, combating crime and ensuring law and order in the state is to develop new approaches and models for shaping its activity, to solve those problems that complicate or render ineffective police activity fulfillment of the tasks set before it. Therefore, highlighting the problematic aspects of police activity that need to be addressed, formulating ways to improve operations in certain areas is a pressing issue.

(C) МАЙОРОВ В.В. - кандидат юридичних наук, докторант (ПрАТ «ВНЗ «Міжрегіональна Академія управління персоналом») 
The article draws attention to the fact that the National Police, as a separate body of executive power, characterizes: service to society by ensuring the protection of human rights and freedoms, combating crime, maintaining public safety and order; it acts on behalf of the State; its activities are directed and coordinated by the Cabinet of Ministers of Ukraine through the Minister of Internal Affairs of Ukraine. Since the establishment of the National Police of Ukraine as a separate central body of executive power, it has been in the systemic process of development. Therefore, the constant changes in public life and the ongoing reforms in the police system require constant study of the organizational, legal, regulatory and information support of the police in order to further find ways to improve the relevant areas of police activity.

The article concludes that the improvement of the mechanisms of information and analytical support of the National Police requires the creation of the concept of development of the information and analytical support of the police on the basis of modern information technologies. The National Police system has not yet been rid of certain regulatory and organizational gaps in its activities that require appropriate scientific elaboration and resolution, in particular as regards: improving the legal and regulatory framework for the functioning of the National Police system. The evaluation of the effectiveness of police activity should not be limited to such an indicator as the level of public trust in the police.

Key words: reforms, police, National Police, Ministry of Internal Affairs of Ukraine, concept, improvements.

Вступ. Згідно з Конституцією України права і свободи людини та їх гарантії визначають зміст і спрямованість діяльності держави. Однак сучасний стан речей диктує складні умови реалізації державою цих положень Конституції. Мова йде не лише про процес нормотворчої діяльність в аспекті створення дієвих механізмів захисту конституційних прав і свобод громадянина України, але й про практичну реалізацію органами публічної влади своїх обов'язків з їх охорони та захисту. Так, центральним органом виконавчої влади, який служить суспільству шляхом забезпечення охорони прав і свобод людини, протидії злочинності, підтримання публічної безпеки і порядку, є саме Національна поліція України.

Нині ефективність діяльності Національної поліції щодо захисту прав і свобод людини та громадянина, протидії злочинності та забезпечення правопорядку в державі полягає в розробці нових підходів і моделей формування іiї діяльності, вирішення тих проблем, які ускладнюють або роблять неефективну діяльність поліції з виконання поставлених перед нею завдань. Тому висвітлення проблемних аспектів у діяльності поліції, які потребують вирішення, формування шляхів удосконалення діяльності у визначених сферах $є$ актуальним питанням.

Науковим підгрунтям написання статті $є$ роботи вітчизняних і зарубіжних вчених. Окремі аспекти діяльності поліції досліджували такі науковці, як О.М. Бандурка, О.К. Безсмертний, І.П. Голосніченко, С.Т. Гончарук, Є.В. Додін, Р.А. Калюжний, А.Т. Комзюк, Ю.Ф. Кравченко, М.І. Мельник, Т.П. Мінка, Р.В. Миронюк та інші. Водночас реформи, що відбуваються в поліції, спонукають до постійних наукових пошуків шляхів вирішення проблем, які виникають на практиці.

Постановка завдання. Мета написання наукової роботи - встановлення актуальних проблем діяльності Національної поліції України на сучасному етапі розвитку держави, а також вироблення пропозицій щодо вдосконалення такої діяльності.

Результати дослідження. У процесі реалізації «Стратегії розвитку органів внутрішніх справ України», затвердженої розпорядженням Кабінету Міністрів України від 22 жовтня 2014 р. № 1118-р та Концепції першочергових заходів реформування системи Міністерства внутрішніх справ, схваленої розпорядженням Кабінету Міністрів України від 22 жовтня 2014 р. № 1118-р було визначено заходи, які сприятимуть створенню оптимальної та ефективної системи Міністерства внутрішніх справ. У підсумку всі заходи з реформування, що були визначені цими документами, у 2014 р. дійсно були нагально необхідними і спрямованими на перетворення системи органів внутрішніх справ відповідно до європейських стандартів. Багато заходів реформи були впроваджені у життя, однак, на жаль, ми змушені констатувати, що окремі $з$ них не були реалізовані.

Так, у Концепції пропонується і специфічний підхід до оцінки якості діяльності Національної поліції України. Вказується, що Національна поліція України відмовляється від статис- 
тичних методів оцінки роботи підрозділів і працівників [1]. У ч. 3 ст. 11 Закону України «Про Національну поліцію» зазначено, що рівень довіри населення до поліції є основним критерієм оцінювання ефективності діяльності органів і підрозділів поліції [2].

Проте, як ми вважаємо, оцінка ефективності діяльності поліції не має обмежуватися таким показником, як рівень довіри населення до поліції. Надаючи оцінку діяльності поліції, довіра населення до неї має залишатися основним, але не визначальним показником. До уваги має братися комплекс факторів (як об'єктивних, так і суб'єктивних), які у своїй сукупності мають визначати, чи є діяльність поліції ефективною.

Говорячи про оцінку ефективності діяльності поліції, в науковій літературі правильно зазначають, що потрібне теоретико-правове переосмислення та практичне впровадження комплексного підходу до оцінювання ефективності діяльності органів і підрозділів поліції України. 3 цього приводу І. Охрименко цілком слушно зазначає, що мають братися до уваги, насамперед, показники об'єктивної статистики щодо злочинних проявів, надійності та компетентності персоналу, оптимального використання наданих ресурсів, а також результати опитування населення 3 проблемних питань діяльності поліції. Саме за таких характеристик можна буде говорити про розробку якісних планів та складання об'єктивних звітів роботи поліції, а звідси - надання правоохоронних послуг, спрямованих на забезпечення публічної безпеки і порядку, охорони прав i свобод людини, протидії злочинності тощо [3, с. 142].

Тому до адміністративно-правових форм оцінювання ефективності забезпечення Національною поліцією публічної безпеки і порядку належать:

1) моніторинг звітів щодо діяльності поліції у відповідній сфері;

2) проведення атестування поліцейських, у тому числі тих, які обіймають керівні посади;

3) проведення опитування серед співробітників поліцейських органів у формі анкетування для визначення проблем та недоліків організації роботи в підрозділах, оцінки методів керівництва, визначення клімату в робочому колективі;

4) проведення анкетування користувачів поліцейських послуг (заявників, потерпілих від правопорушень, правопорушників тощо) з метою визначення якісних характеристик діяльності поліції та їі окремих підрозділів;

5) вивчення громадської думки, рівня довіри населення (соціологічні дослідження) [4, с. 63].

Щодо першого показника стосовно моніторингу звітів щодо діяльності поліції у відповідній сфері, то тут варто вказати на те, що у процесі оцінці ефективності діяльності поліції має бути оцінено кількість злочинів, які було вчинено, їх динаміка, а також стан їх розкриття, встановлення осіб, які їх вчинили, показники виявлених злочинів на стадії їх підготовки тощо. На нашу думку, такий підхід має бути покладений в основу визначення ефективності діяльності поліції.

Наступний момент, на який хотілося б звернути увагу, - це проблема здійснення керівництва органами та підрозділами поліції.

Реформи, які відбуваються не тільки в поліції, але й у МВС України (МВС України є органом, який спрямовує діяльність поліції), висувають нові вимоги до особистих і професійних якостей до працівників керівної ланки як Національної поліції України, так і МВС України. Ефективність діяльності органів та підрозділів поліції напряму залежить від особистості керівника, його професійних, ділових та моральних якостей, здатності належним чином організувати роботу підлеглих, у зв'язку з чим питання професіоналізму керівника, рівня їхньої управлінської компетенції є доволі актуальними.

Тому вкрай важливим є якісний і прозорий відбір кандидатів для зарахування до резерву керівного складу органів Національної поліції. Головними елементами цього відбору мають стати: об'єктивна оцінка їхніх особистих і ділових якостей; навчання кандидатів, котрі перебувають у складі резерву; вибір і призначення на вакантні посади найбільш придатних працівників та аналіз їхньої діяльності [5]. Нині варто відходити від практики, коли на посади керівників призначаються працівники без необхідного досвіду роботи, які не мають необхідного рівня професіоналізму.

Керівнику органу чи підрозділу Національної поліції України, передусім, необхідно оволодіти сукупністю знань, умінь і навичок, які б дали змогу: забезпечити функціонування органу чи його структурного підрозділу відповідно до сучасних умов і вимог; критично оцінювати та прогнозувати економічні, політичні, культурні та соціальні події і явища; розуміти сучасні проблеми управлінської діяльності та технології адміністративної роботи; розробляти та впроваджувати нові підходи та ідеї; аналітично мислити; вільно орієнтуватися в чинному законодавстві, що регламентує професійну діяльність, а також належному оформленні службової документації; 
поєднувати фундаментальні знання з практикою; використовувати сучасну методологію розробки, прийняття й обгрунтування управлінських рішень 3 обов'язковим врахуванням загальнолюдських цінностей [5].

Нині вкрай важливо, щоб у системі Національної поліції України були саме компетентні керівники-професіонали, спроможні підтверджувати новітній стиль роботи і сучасні форми управління органами та підрозділами Національної поліції, а не просто високоосвічені люди 3 практичним і життєвим досвідом. В органах поліції має бути запроваджений адекватний потребам практики та прозорий механізм відбору кадрів та кар'єрного зростання, безперервного професійного розвитку персоналу.

Наслідком певних прогалин в організації керівництва органами та підрозділами поліції $\epsilon$ те, що система Національної поліції досі не позбавилась певних нормативних та організаційних прогалин у власній діяльності, які потребують відповідного наукового опрацювання та вирішення, зокрема в частині: вдосконалення нормативно-правового регулювання функціонування системи Національної поліції; удосконалення практики планування власної діяльності, використання ресурсів за стратегічними напрямками; запровадження дієвих механізмів забезпечення прозорості відбору кадрів і кар’єрного зростання, впровадження програм безперервного професійного розвитку персоналу та ін. [6]

Іншим проблемним моментом, який потребує вирішення, є питання оптимізації системи та чисельності органів поліції.

Так, відповідно до ст. 13 Закону України «Про Національну поліцію» загальна чисельність поліції, що утримується коштом Державного бюджету України, до 1 січня 2018 р. не може перевищувати 140000 осіб. Відповідно до ч. 5 ст. 21 Закону України від 27.02.2014 р. «Про Кабінет Міністрів України» Кабмін затверджує граничну чисельність працівників міністерств та інших центральних органів виконавчої влади в межах коштів, передбачених у Державному бюджеті України для утримання органів виконавчої влади, але нині таке рішення відсутнє [6]. Тому варто зазначити, що чисельність працівників поліції не має залежати від наявності чи відсутності коштів, передбачених у Державному бюджеті України для утримання органів виконавчої влади, а зумовлюватися станом та рівнем злочинності, потребами практичної діяльності

Наступне питання, на яке варто звернути увагу, - це модернізація інформаційно-аналітичного забезпечення діяльності Національної поліції, яке має відбуватися шляхом впровадження сучасних інформаційно-комунікаційних технологій та нових моделей управління інформацією, наприклад, у вигляді моделі правоохоронної діяльності, керованої аналітикою.

Поліція кожен день отримує інформацію в різній формі, але сама по собі інформація не несе жодної користі. Ї̈̈ потрібно порівняти, проаналізувати та поширити. Аналіз та інтерпретація цієї інформації визначають реагування та політику поліції та дає змогу направляти ресурси туди, де вони найбільш потрібні. Це також доповнюється «аналізом ризиків», що також є важливою частиною правоохоронної діяльності, керованої аналітикою. Правоохоронна діяльність, керована аналітикою, дійсно дає нам змогу бачити ширшу картину, визначаючи тенденції та зразки (почерк), шляхом пов'язування між собою злочинів, об'єктів, осіб, ознак, місця через проведення кримінального аналізу. Інформація, що надходить від громади, - одна 3 найважливіших складових частин роботи правоохоронних органів, керованої аналітикою, як і в моделі взаємодії поліції з громадами (community policing). Насправді ж обидві згадані моделі роботи поліції не можуть належним чином функціонувати одна без одної [7].

Таким чином, удосконалення механізмів інформаційно-аналітичного забезпечення Національної поліції потребує створення концепції розвитку інформаційно-аналітичного забезпечення поліції на основі сучасних інформаційних технологій, розроблення комплексу організаційно-правових і технічних заходів та засобів, націлених на поліпшення інформаційних зв’язків між органами та підрозділами поліції, між Національною поліцією та МВС України, створення законодавчого та технічного забезпечення у впровадженні інформаційно-аналітичних інновацій із залученням компетентних IT-фірм та організацій тощо.

Висновки. Національну поліцію як окремий орган виконавчої влади характеризує таке: служіння суспільству шляхом забезпечення охорони прав і свобод людини, протидії злочинності, підтримання публічної безпеки і порядку; вона виступає від імені держави; ії діяльність спрямовується та координується Кабінетом Міністрів України через Міністра внутрішніх справ України. 3 моменту створення Національної поліції України як окремого центрального органу виконавчої влади вона перебуває в системному процесі розбудови. Тому постійні зміни в суспільному житті, 
реформи, що тривають в системі поліції, потребують постійного вивчення питань організаційно-правового, нормативного, інформаційного забезпечення поліції з метою подальшого пошуку шляхів покращення відповідних напрямів діяльності поліції.

\title{
Список використаних джерел:
}

1. Концепція «100 днів якості Національної поліції України». URL: http://umdpl.info/ police-experts.info/2016/12/29/kontseptsiya-100-dniv-yakosti-natsionalnoji-politsiji/.

2. Про Національну поліцію : Закон України від 02.07.2015 p. № 580-VIII. URL: http:// zakon2.rada.gov.ua/laws/show/580-19/paran5\#n5.

3. Охрименко І. Оцінка ефективності діяльності органів і підрозділів Національної поліції України: погляди на проблему. Підприємниитво, господарство і право. 2016. № 11. С. 139-144.

4. Батраченко О.В. Удосконалення системи оцінювання ефективності забезпечення Національною поліцією України публічної безпеки та порядку. Право.Uа. 2016. № 1. С. 58-63.

5. Лясковська О.А. Керівник в органах і підрозділах Національної поліції України як організатор управління. Науковий вісник публічного та приватного права. 2017. № 3. С. 114-118. URL: http://www.nvppp.in.ua/vip/2017/3/24.pdf.

6. Бугайчук К.Л. Деякі питання вдосконалення діяльності органів та підрозділів Національної поліції України. Право і безпека. 2019. № 2(73). С. 13-19.

7. Правоохоронна діяльність, керована аналітикою; передова методика правоохоронної діяльності. URL: http://www.euam-ukraine.eu/ua/news/latest-news/pravoohoronna-diyalnist-kerovanaanalitikoyu-peredova-metodika-suchasnoyi-pravoohoronnoyi-diyalnosti/.

УДК 342

DOI https://doi.org/10.32844/2618-1258.2019.5-2.29

МОРГУНОВ О.А.

\section{МОДЕЛІ ПУБЛІЧНОГО АДМІНІСТРУВАННЯ СФЕР ФІЗИЧНОЇ КУЛЬТУРИ ТА СПОРТУ: ЗАКОРДОННИЙ ДОСВІД}

\begin{abstract}
Метою статті є визначення прийнятної для основи реформування в Україні моделі публічного адміністрування сфер фізичної культури та спорту, визначення ii особливостей. Так, у статті визначено прийнятну для основи реформування в Україні модель публічного адміністрування сфер фізичної культури та спорту, встановлено її особливості як основу для розроблення напрямів удосконалення відповідної діяльності. 3'ясовано, що радянська система управління в галузі фізичної культури й спорту знаходить прояв в обгрунтуванні і доведенні переваг соціалістичної системи фізичного виховання над капіталістичною, жорсткому придушенні тенденцій розвитку фізичної культури й спорту на основі національних, етнічних засад. Наголошено на тому, що традиційно найважливішу роль в американському спортивному русі відіграє професійний спорт, який розвивається професійними спортивними лігами, асоціаціями, спілками, а також клубами-командами. Професійний спорт у США має яскраво виражену специфіку. Його стійке положення базується на високому попиті на його продукт, яким є видовище. Якщо вид спорту стає збитковим, то він припиняє своє існування як професійний. Видовище - це продукт діяльності всіх команд ліги. Визначено, що європейська модель управління сферами фізичної культури сформувалась на основі практики спільного управління різними видами спорту в Європі. Зроблено висновок про те, що для України доцільною є орієнтація на європейську модель, що характеризується активною співпрацею влади та суспільства, чому сприяє розгалужена пірамідально ієрархічна функціонально-допоміжна структура системи публічного адміністрування; правотворчістю як основ-
\end{abstract}

(C) МОРГУНОВ О.А. - кандидат юридичних наук, доцент, докторант (Харківський національний університет внутрішніх справ) 